\title{
Front Matter: Volume 10416
}

, "Front Matter: Volume 10416," Proc. SPIE 10416, Optical Coherence Imaging Techniques and Imaging in Scattering Media II, 1041601 (6 November 2017); doi: 10.1117/12.2291713

SPIE. Event: European Conferences on Biomedical Optics, 2017, Munich, Germany 


\title{
PROGRESS IN BIOMEDICAL OPTICS AND IMAGING
}

\section{Optical Coherence Imaging Techniques and Imaging in Scattering Media II}

\author{
Maciej Wojtkowski \\ Stephen A. Boppart \\ Wang-Yuhl Oh \\ Editors
}

25-29 June 2017

Munich, Germany

Sponsored by

The Optical Society (United States)

SPIE

Published by

SPIE 
The papers in this volume were part of the technical conference cited on the cover and title page. Papers were selected and subject to review by the editors and conference program committee. Some conference presentations may not be available for publication. Additional papers and presentation recordings may be available online in the SPIE Digital Library at SPIEDigitallibrary.org.

The papers reflect the work and thoughts of the authors and are published herein as submitted. The publisher is not responsible for the validity of the information or for any outcomes resulting from reliance thereon.

Please use the following format to cite material from these proceedings:

Author(s), "Title of Paper," in Optical Coherence Imaging Techniques and Imaging in Scattering Media II, edited by Maciej Wojtkowski, Stephen A. Boppart, Wang-Yuhl Oh, Proceedings of SPIE Vol. 10416 (SPIE, Bellingham, WA, 2017) Seven-digit Article CID Number.

ISSN: 1605-7422

ISSN: 1996-756X (electronic)

ISBN: 9781510612907

ISBN: 9781510612914 (electronic)

Copublished by

SPIE

P.O. Box 10, Bellingham, Washington $98227-0010$ USA

Telephone +1 3606763290 (Pacific Time) · Fax +1 3606471445

SPIE.org

and

\section{The Optical Society}

2010 Massachusetts Ave., N.W., Washington, D.C., 20036 USA

Telephone 1 202/223-8130 (Eastern Time) · Fax 1 202/223-1096

http://www.osa.org

Copyright @ 2017, Society of Photo-Optical Instrumentation Engineers.

Copying of material in this book for internal or personal use, or for the internal or personal use of specific clients, beyond the fair use provisions granted by the U.S. Copyright Law is authorized by SPIE subject to payment of copying fees. The Transactional Reporting Service base fee for this volume is $\$ 18.00$ per article (or portion thereof), which should be paid directly to the Copyright Clearance Center (CCC), 222 Rosewood Drive, Danvers, MA 01923. Payment may also be made electronically through CCC Online at copyright.com. Other copying for republication, resale, advertising or promotion, or any form of systematic or multiple reproduction of any material in this book is prohibited except with permission in writing from the publisher. The CCC fee code is 1605 $7422 / 17 / \$ 18.00$.

Printed in the United States of America.

Publication of record for individual papers is online in the SPIE Digital Library.

\section{SPIE. DIGRARY}

SPIEDigitalLibrary.org

Paper Numbering: Proceedings of SPIE follow an e-First publication model. A unique citation identifier (CID) number is assigned to each article at the time of publication. Utilization of CIDs allows articles to be fully citable as soon as they are published online, and connects the same identifier to all online and print versions of the publication. SPIE uses a seven-digit CID article numbering system structured as follows:

- The first five digits correspond to the SPIE volume number.

- The last two digits indicate publication order within the volume using a Base 36 numbering system employing both numerals and letters. These two-number sets start with 00, 01, 02, 03, 04, 05, 06, 07, 08, 09 , OA, OB ... OZ, followed by 10-1Z, 20-2Z, etc. The CID Number appears on each page of the manuscript. 


\title{
Contents
}

\author{
vii Authors \\ ix Conference Committee
}

\section{PHASE SENSITIVE AND DOPPLER IMAGING}

1041602 Lateral resonant Doppler flow measurement by spectral domain optical coherence tomography [10416-18]

1041603 Performance comparison of spectrometer based and swept source based phase sensitive optical coherence tomography [10416-1]

\section{OPHTHALMIC OCT IMAGING}

1041604 Dosimetry control and monitoring of selective retina therapy using optical coherence tomography [10416-4]

1041605 A high en-face resolution AS-OCT providing quantitative ability to measure layered corneal opacities [10416-6]

\section{ADVANCES IN OPTICAL COHERENCE IMAGING TECHNOLOGY I}

1041606 Super-resolved thickness maps using ultrahigh resolution OCT [10416-8]

1041607 Sequential multi-channel OCT in the retina using high-speed fiber optic switches [10416-17]

1041608 Comparison between a supercontinuum source and a titanium sapphire laser in achieving ultrahigh resolution spectral domain optical coherence tomography (SD-OCT) [10416-37]

OPTICAL COHERENCE IMAGING OF BRAIN TISSUE

1041609 Bessel beam OCM for analysis of global ischemia in mouse brain [10416-36]

10416 OA Optical coherence tomography for compound action potential detection: a computational study [10416-9]

\section{ADVANCES IN OPTICAL COHERENCE IMAGING TECHNOLOGY II}

10416 OB Novel software package to facilitate operation of any spectral (Fourier) OCT system [10416-5] 
10416 OC Imaging through scattering media by Fourier filtering with a single-pixel camera [10416-12]

10416 OD Imaging through a scattering medium based on spatial transmission matrix [10416-10]

\section{POLARIZATION SENSITIVE OPTICAL COHERENCE IMAGING}

10416 OE Multi-functional optical coherence tomography imaging of spontaneous neovascularization in the mouse retina [10416-23]

\section{MEDICAL APPLICATIONS OF OPTICAL COHERENCE TOMOGRAPHY}

10416 OF 3D handheld endoscope for optical coherence tomography of the human oral mucosa in vivo [10416-16]

\section{SPECKLES AND COHERENCE IMAGING}

10416 OG Rapid identification of coherent pupil functions from multiple intensity measurements [10416-11]

$10416 \mathrm{OH}$ Measuring tissue dispersion using optical coherence tomography speckle [10416-35]

10416 ol Evaluation of the temporal auto-correlation function sensitivity to Brownian motion in the radiative transport regime [10416-22]

\section{ADVANCES OF OCT FOR EYE IMAGING}

10416 0J 1060nm FDML laser with centimeter coherence length and $1.67 \mathrm{MHz}$ sweep rate for full eye length and retinal ultra-widefield OCT [10416-24]

10416 OK Combining FF-OCT with SD-OCT for retinal imaging [10416-2]

\section{ADVANCES IN OPTICAL COHERENCE IMAGING TECHNOLOGY III}

$10416 \mathrm{OL}$ Long-range live 3D-OCT at different spectral zoom levels [10416-33]

$104160 \mathrm{M}$ Few-mode fiber detection for tissue characterization in optical coherence tomography [10416-34]

$10416 \mathrm{ON}$ Master/slave: a better tool for Gabor filtering optical coherence tomography imaging instruments [10416-14] 
1041600 Evaluation of the optimal steepest ascent algorithm for focusing light through turbid media [10416-500]

10416 OP Quasistatic in-depth local strain relaxation/creep rate mapping using phase-sensitive optical coherence tomography [10416-7]

10416 OQ Simulation of image formation in optical coherence tomography for cylinder scatterers [10416-21]

10416 OR Quantitative, simultaneous, and collinear eye-tracked, high dynamic range optical coherence tomography at 850 and $1060 \mathrm{~nm}$ [10416-20]

10416 OS Incoherent light sources for speckle reduction in double pass ocular imaging [10416-15] 
Proc. of SPIE-OSA Vol. 10416 1041601-6

Downloaded From: https://www.spiedigitallibrary.org/conference-proceedings-of-spie on 26 Apr 2023 Terms of Use: https://www.spiedigitallibrary.org/terms-of-use 


\section{Authors}

Numbers in the index correspond to the last two digits of the seven-digit citation identifier (CID) article numbering system used in Proceedings of SPIE. The first five digits reflect the volume number. Base 36 numbering is employed for the last two digits and indicates the order of articles within the volume. Numbers start with 00, 01, 02, 03, 04, 05, 06, 07, 08, 09, 0A, OB...0Z, followed by 10-1Z, 20-2Z, etc.

Aranha dos Santos, Valentin, 06

Arnold, Patrik, 04, OR

Augustin, Marco, 07, OE, OM

Bang, Ole, ON

Baumann, Bernhard, 07, OE, OM

Baumann, Michael, OF

Beer, Florian, 07

Boccara, A. Claude, OK

Bousi, Evgenia, $\mathrm{OH}$

Bradu, Adrian, OB, ON

Brenner, Thomas, $O Q$

Burri, Christian, 04, OR

Caujolle, S., 08

Cernat, Ramona, ON

Chen, Wei-Li, 05

Chiu, Yu-Kuang, 05

Clemente, P., OC

Constandinou, Timothy G., OA

Da Silva, Anabela, 0

de longh, Gijs, OG

Dobre, George, 03

Dolezyczek, Hubert, 09

Draxinger, Wolfgang, $\mathrm{OL}$

Druzhkova, Irina N., OP

Durduran, Turgut, 0 I

Ebert, Nadja, OF

Eugui, Pablo, OM

Feuchter, T., 08

Fialová, Stanislava, OE, OM

Fink, Mathias, OK

Garway-Heath, David, ON

Gelikonov, Grigory V., OP

Gelikonov, Valentin M., OP

Geng, Yi, OD

Gladkova, Natalia D., OP

Grill, Christin, OL

Gubarkova, Ekaterina V., OP

Haindl, Richard, 07

Halpaap, Donatus, OS

Harper, Danielle J., OM

$\mathrm{He}$, Zhengquan, OD

Hitzenberger, Christoph K., 07, OE, OM

$\mathrm{Hu}$, Yong, 03

Huang, Sheng-Lung, 05

Huber, Robert, OJ, OL

Istraelsen, Niels Moller, ON

Jauregui-Sánchez, Y., OC

Justiz, Joern, 04

Karashtin, Dmitry A., OP
Kaufmann, Daniel, 04

Keane, Pearse A., ON

Kienle, Alwin, $0 Q$

Klee, Julian, 0J

Koch, Edmund, 02, OF

Koch, Volker M., 04

Kolb, Jan Philip, 0J

Lancis, J., OC

Leitgeb, Rainer A., 06

Lichtenegger, Antonia, OM

Liu, Quan, 00

Luggen, David, OR

Macdonald, Callum M., 0 I

Malinowska, Monika, 09

Markel, Vadim A., Ol

Marques, M. J., OB

Masoller, Cristina, OS

Matveev, Lev A., OP

Matveyev, Alexander L., OP

Meier, Christoph, 04, OR

Mooser, Matthias, OR

Nikolic, Konstantin, OA

Peyer, Michael, OR

Pfeiffenberger, Ulrike, OE

Pfeiffer, Tom, OJ, OL

Photiou, Christos, $\mathrm{OH}$

Pircher, Michael, 07

Pitris, Costas, $\mathrm{OH}$

Podoleanu, Adrian, 08, OB, ON

Považay, Boris, 04, OR

Pozzi, Paolo, OG

Rajendram, Ranjan, ON

Rapolu, Mounika, 09

Reitzle, Dominik, $0 Q$

Ren, Liyong, OD

Rivet, Sylvain, OB, ON

Schmetterer, Leopold, 06

Schnabel, Christian, OF

Shabanov, Dmitry V., OP

Sirotkina, Marina A., OP

Soldevila, F., OC

Soloviev, Oleg, OG

Sovetsky, Aleksandr A., OP

Stoller, Markus, OR

Szkulmowski, Maciej, 09

Tajahuerce, E., OC

Tamborski, Szymon, 09

Tricoli, Ugo, Ol

Triggs, Graham J., 06 
Troiani, Francesca, OA

Tsai, Cheng-Tsung, 05

Unterhuber, A., 08

Vdovin, Gleb, OG

Verhaegen, Michel, OG

Verma, Manish, 00

Vilaseca, Meritxell, OS

Vitkin, Alex, OP

Walther, Julia, 02, OF

Wartak, Andreas, 07, OM

Wechdorn, Matthias, OE

Werkmeister, René M., 06, 08, 0E

Wilczynski, Grzegorz, 09

Wilding, Dean, OG

Wojtkowski, Maciej, 09

Xiao, Peng, OK

$X U$, Chengfang, OD

Yang, Chang-Hao, 05

Zagaynova, Elena $\mathrm{V}$., OP

Zaitsev, Vladimir Yu., OP

Zhao, Guangzhi, OD

Zhou, Libin, OD

Zhuang, Bin, OD

Zouvani, loanna, $\mathrm{OH}$ 


\title{
Conference Committee
}

\author{
General Chair
}

Rainer Leitgeb, Medizinische Universität Wien (Austria)

Program Chairs

Brett E. Bouma, Wellman Center for Photomedicine (United States)

Paola Taroni, Politecnico di Milano (Italy)

Conference Chairs

Maciej Wojtkowski, Nicolaus Copernicus University (Poland)

Stephen A. Boppart, Beckman Institute for Advanced Science and Technology (United States)

Wang-Yuhl Oh, KAIST (Korea, Republic of)

Conference Programme Committee

Andy Yun, Massachusetts General Hospital (United States)

Peter E. Andersen, Technical University of Denmark (Denmark)

Silvain Gigan, Institut Langevin (France)

Adrian Podoleanu, Kent University (United Kingdom)

Michael Pircher, Medizinische Universität Wien (Austria)

Ivo Velekoop, Universiteit Twente (Netherlands)

James G. Fujimoto, Massachusetts Institute of Technology (United States)

Robert A. Huber, Universität zu Lubeck (Germany)

David D. Sampson, The University of Western Australia (Australia)

Wonshik Choi, Korea University (Korea, Republic of)

Valentin Gelikonov, Institute of Applied Physics (Russian Federation)

Yoshiaki Yasuno, University of Tsukuba (Japan)

Johannes F. de Boer, Vrije Universiteit Amsterdam (Netherlands)

Alfredo Dubra, Stanford University (United States)

Michel Choma, Yale University (United States)

Benjamin J. Vakoc, Wellman Center for Photomedicine

(United States) 
Proc. of SPIE-OSA Vol. 10416 1041601-10

Downloaded From: https://www.spiedigitallibrary.org/conference-proceedings-of-spie on 26 Apr 2023
Terms of Use: https://www.spiedigitallibrary.org/terms-of-use Terms of Use: https://www.spiedigitallibrary.org/terms-of-use 